\title{
研究課題別事後評価結果
}

1. 研究課題名： 細胞における確率的分子情報処理のゆらぎ解析

2. 研究代表者名及び主たる研究参加者名 (研究機関名・職名は研究参加期間終了時点)：

研究代表者

上田 昌宏 (大阪大学 理学研究科 教授)

主たる共同研究者

柴田 達夫（(独) 理化学研究所 発生・再生科学総合研究センター

$$
\text { ユニットリーダー) }
$$

高木 拓明（奈良県立医科大学 医学部 講師）

\section{3. 研究概要}

細胞は分子運動・分子反応の確率性に起因寸るゆらぎを内包した動的システムである。確率的にはたらく分 子を要素として情報処理機能・運動機能などを有するシステムが自律的に組織化されている。本研究では、細 胞内の確率的分子情報処理システムの構築原理を理解することを目的として、分子運動や分子反応の確率性 (ゆらぎ)に着目した1分子レベルからの定量的イメージング解析技術と、そこで得られる不規則時系列データの 統計解析法を開発し、実験結果に基づいた理論・数理モデルの構築を行った。3つのサブグループ間の密な連 携により、定量的イメージング解析法と理論・数理モデル解析を統合的に用いる方法論を実現し、細胞の走化 性応答を担う情報処理システムに適用した。これにより、確率的にはたらく分子から構成された情報処理システ ムが、情報処理機能や運動調節機能を発現する際の機能発現ダイナミクスを 1 分子・分子ネットワーク・細胞の 各階層において時間的・空間的に追跡・解析することを可能にした。

こうした研究の結果、走化性の情報処理システムは”興奮系 (excitable system)”であることが明らかになっ た。興奮系の特性を有寸るシステムが確率的にはたらく分子から自己組織化メカニズムにより形成される。こうし たシステムの構築原理により、分子レベルでの「分子数ノイズ」が細胞レベルでの確率的な行動 (ゆらぎ探索)を 可能にし、変動する環境に対して柔軟な適応を実現している(organized randomness，構造化された確率性)。 これらの知見は、同時にまた、細胞の自発性の起源と意義も明らかにしている。すなわち、分子運動や分子反 応の確率性を起源として細胞の自発的なダイナミクスが生み出され、自発性が利用されて柔軟な環境適応が実 現されている。

\section{4. 事後評価結果}

4-1. 研究の達成状況及び得られた研究成果 (論文・口頭発表等の外部発表、特許の取得状況等を含む)

細胞内1分子イメージング解析の自動化により多種分子の迅速な1分子解析を実現させ、分子運動、分子反 応の確率性の数式化に成功した。多階層間のダイナミックスの解明に向けた端緒を見つけており、目標は達成 できている。さらに、走化性のシグナルとして興奮系が働いているといら極めて興味ある成果を挙げるまでに到っ ている。

ゲノムの世界と分子集合の世界の関連についての考え方を提示し、研究代表者のゼロからのコンセプトを組 み立てる能力は大変優れている。45 回にもおよぶチーム内ミーティングを行い、3つのサブグループ間の密接 で強固な協働作業によってなし得たものであり、この分野では、これまでに例を見ない優れた協同研究の成果 であることも、高く評価したい。 
実験と理論を組み合わせた論文の発表にこだわって努力したことが窺え、その点も評価できる。さらに、この コンセプトを積極的に、国際的に示すことを望む。

Cell 関連誌、Proc. Natl. Acad. Sci. USA, PLoS ONE などを含む22報の原著論文を国際誌に発表した。 招待講演（国内会議 44 件、国際会議 24 件)や学会発表(国内会議 63 件、国際会議 3 件)、ポスター発表 (国内会議 82 件、国際会議 38 件)など積極的に成果を発表していることは、高く評価され、実験と理論を兼ね 備えた若手研究者の育成にも貢献している。

生命システム動態の原理の普遍性を提唱しようとするものであり、この段階で、知的財産権を論議するには 当たらない。

4-2. 研究成果の科学技術や社会へのインパクト、戦略目標への貢献

生命システムの動作原理を明らかにするために、実験系と理論を極めて有効に融合したもので戦略目標の 目的に合致しており、今後、他の生命システム研究の模範となるであろう。

細胞膜上のシグナル伝達分子全般に適用しうる 1 分子拡散とキネティックスの解析法の基盤技術を開発し、 また、これを 1 分子輝点自動追跡ソフトー組み込んで細胞内での分子状態イメージングを実現したことは、極め てインパクトの高い技術的上の成果である。また、興奮系からなるシステムの階層の解析では、1つの新しい概 念として浸透することが期待される成果を得ており、他の生物学領域への拡がりが期待され、生命科学に大きな 影響を与える成果に発展しつつある。

\section{4-3. 総合評価}

実験と理論の研究グループが緊密に協力して、「構造化された確率性」仮説について解析し、具体的に、 分子実態として、三量体 Gタンパク質とイハシトールリン脂質の挙動を同定して、興奮系システムが主要な役割 を果たしていることまで明確に示した成果は高く評価する。優れた協同研究の結果によるものである。また、粘 菌細胞以外の細胞への適用について、免疫系細胞への適用を試みるなどの努力は評価できる。

本研究の展開には、実験と理論の二つの専門グループの緊密な協力体制が不可欠であったが、リーダーシ ップを発揮し、実験チームと情報解析・理論チームを上手く連携させ、まとめて、目標を達成したことは、大いに 評価される。その結果として、実験と理論の両方を習得した人材を数多く、輩出している点は、特記しておきた い。研究費の執行状況については、特に問題は見受けられない。

この成果は、細胞の行動反応の原理として広い分野に影響を与えると期待され、国際的にも注目されてい る。外部発表において、論文・口頭発表も、質、数ともに十分である。

この延長線上で、今まで説明できなかった粘菌の動態を解明するといらところまで、到達することを期待した い。 